\title{
MENINGKATKAN KUALITAS HIDUP DAN PENATAAN HIDUP MASYARAKAT MELALUI BUMDES
}

\author{
Hasmiyatul Haryani ${ }^{1}$, Evalinda Juniarti ${ }^{2}$, Opi Ayu Rimadani ${ }^{3}$, Didin Hadi Saputra ${ }^{4}$, Arfan $^{5}$ \\ 1,2,3,4,5 Universitas Nahdlatul Wathan Mataram \\ hasher@gmail.com, evajun@gmail.com, opia@gmail.com, didinimarc@gmail.com \\ arfan@gmail.com
}

\begin{abstract}
Community Service Activities (ABDIMAS) is one of the implementation or practice of knowledge that is in the Tri Dhrama contained in the fourth (4) dharma, this is included in. Service can be combined with a combination of information technology and cultural arts directly to the community as an institution. The problem or problem that has been identified in this community service activity is that the role of BUMDes is still not optimal in the context of the community welfare media in the Village of East Lombok Regency. In overcoming this problem, the solution we have provided is, initial socialization and discussion to determine the model and direction of strengthening and developing BUMDes in Pengangkal Village in East Lombok. The purpose of this community service activity is to strengthen and develop BUMDes to sustain and make the social quality of the community more independent and modern. The method used in this service is the method of lectures and discussions with the village, BUMDes managers, and partners. The completion step in this service is to compose a grand design in the form of community empowerment towards a better direction, as well as carrying out a process of assistance and training.
\end{abstract}

\section{Keywords: BUMDes Bao Daya, BUMDes Partners, Pringgasela}

\begin{abstract}
Kegiatan Pengabdian kepada Masyarakat (ABDIMAS) merupakan salah satu pelaksanaan atau pengamalan ilmu pengetahuan yakni dalam Tri Dhrama terdapat di dharma ke empat (4), hal ini termasuk dalam. Pengabdian dapat dikombinasikan dengan perpaduan teknologi informasi, dan seni budaya langsung pada masyarakat secara kelembagaan. Persoalan atau masalah yang diidentifikasikan muncul dalam kegiatan pengabdian ini adalah masih kurang optimalnya peran BUMDes didalam rangka media penyejahteraan hidup masyarakat di Desa Pengadangan Lombok Timur. Dalam mengatasi persoalan tersebut, solusi yang kami berikan yakni, sosialisasi dan diskusi awal untuk menentukan model dan arah penguatan dan pengembangan BUMDes Desa Pengadangan di Lombok Timur. Tujuan dari kegiatan pengabdian ini adalah untuk lebih menguatkan serta mengembangkan BUMDes untuk menopang dan membuat kualitas sosial masyarakat lebih mandiri dan modern. Metode yang digunakan dalam pengabdian ini adalah metode ceramah dan diskusi bersama pihak desa, pengelola BUMDes, dan pihak mitra. Langkah penyelesaian dalam pengabdian ini adalah menyusun grand design dalam bentuk pemberdayaan masyarakat menuju kea rah yang lebih baik, serta melakukan proses pendampingan dan pelatihan.
\end{abstract}

Kata kunci : BUMDes Bao Daya, Mitra BUMDes, Pringgasela 
PENDAHULUAN

Kegiatan Pengabdian kepada Masyarakat (ABDIMAS) merupakan salah satu pelaksanaan atau pengamalan ilmu pengetahuan yakni dalam Tri Dhrama terdaat di dharma ke empat (4), hal ini termasuk dalam. Pengabdian dapat dikombinasikan dengan perpaduan teknologi informasi, dan seni budaya langsung pada masyarakat secara kelembagaan.

Dalam kegiatan pengabdian ini, masalah yang utama dibahas dan di diskusikan adalah penyusunan grand design atau design utama dalam BUMDes, agar kegiatan yang akan dilakukan atau kegiatan yang akan dilaksanakan di BUMDes Bao Daya di desa Pringgasela mampu memberikan efek atau dampak nyata kepada masyarakat sekitar, serta mampu memberikan manfaat yang lebih luas, agar kualitas dan tatanan hidup masyarakat di daerah setempat bisa berkembang dengan baik dan pesat

Melalui kegiatan Dharma Pengabdian, seorang akademisi (dalam hal ini seorang dosen) menggunakan metodologi ilmiah sebagai sarana penyebaran atau sarana diseminasi Tri Dharma Perguruan Tinggi serta tanggung jawab yang baik dalam usaha mengembangkan

kemampuan

masyarakat, sehingga dapat mempercepat laju pertumbuhan tercapainya tujuan pembangunan nasional.

Melalui kegiatan pengabdian masyarakat ini juga akan diketahui seberapa penting dan mendesak pelaksanaan kegiatan pendampingan, penguatan dan pengembangn BUMDes Bao Daya berbasis masalah lapangan. Hal ini juga merupakan merupakan salah satu dari kegiatan pokok dalam Tri Dharma Perguruan Tinggi Selain Pendidikan dan Penelitian, sesuai undang-Undang RI Nomor 20 Tahun 2003 tentang Sistem Pendidikan Nasional, pada Pasal 20 ayat 2 dinyatakan: "Perguruan Tinggi berkewajiban menyelenggarakan pendidikan, penelitian dan pengabdian masyarakat". Pada Pasal 24 ayat 2 disebutkan:"Perguruan tinggi memiliki otonomi untuk mengelola sendiri lembaganya sebagai pusat penyelenggaraan pendidikan tinggi, penelitian ilmiah, dan pengabdian masyarakat".

Kegiatan Program pengabdian kepada masyarakat merupakan salah satu dari sekian jenis program yang wajib dilaksanakan, baik oleh dosen 
maupun oleh mahasiswa, dengan berlandaskan pada prinsip-prinsip: motivasi pemenuhan kompetensi akademik, jiwa kewirausahaan (entrepreneurship), dan profesional, sehingga dapat melahirkan program atau kegiatan pengabdian yang unggul kepada masyarakat yang akan menghasilkan outcome yang bermutu, relevan, sesuai dnegan tuntutan zaman, serta sinergis dalam meningkatkan pemberdayaan masyarakat di kancah global.

Pemberdayaan masyarakat yang baik, pada umumnya mensyaratkan adanya proses pendampingan dan pelatihan. Pendampingan diperlukan karena objek pemberdayaan masyarakat adalah masyarakat yang memiliki dinamika yang beragam sedangkan pelatihan merupakan suatu upaya yang digunakan untuk meningkatkan keterampilan yang dibutuhkan untuk melaksanakan pekerjaan sekarang. (Kewirausahaan et al. 2019)

Seperti yang diungkap dalam penelitian yang dilakukan oleh (Lansia et al. 2017), pemberdayaan dapat menjadi salah satu pendekatan pembangunan dalam proses penguatan ekonomi dan sosial untuk meningkatkan kesejahteraan hidup masyarakat, utamanya di pedesaan. Pendapat lain juga diungkapkan dalam penelitian yang dilakukan oleh (Widiastuti and Widyaswati 2018), yang mengungkapkan bahwa pemberdayaan masyarakat dilakukan untuk meningkatkan kesejahteraan masyarakat serta untuk meningkatkan keterampilan warga masyarakat.

Kegiatan pengabdian ini bertujuan untuk membentuk pola pikir yang kreatif, terbuka, dan inovatif pada BUMDes Bao Daya yaitu melalui diskusi serta manajemen BUMDes yang baik.

Salah satu Kelurahan atau desa di Propinsi NTB yang juga merupakan salah satu desa atau kelurahan yang dikategorikan masih perlu didampingi kegiatan abdimasnya yakni Desa Pengadangan. Pengadangan adalah salah satu desa yang terletak di Kecamatan Pringgasela, Kabupaten Lombok Timur, Provinsi Nusa Tenggara Barat, Indonesia. Desa ini terletak di bawah kaki Gunung Runjani.

Desa Pengadangan mempunyai Bumdes, bernama Bao Daya, namun keberadaan BUMDes ini masih belum bisa mandiri dalam mengelola potensi desa yang bisa dikatakan sangat banyak dan memiliki kondisi geografis yang 
cukup baik, melalui kegiatan pengabdian yang bertemakan

Meningkatkan Kualitas Hidup Dan

Penataan Hidup Masyarakat Melalui

Bumdes, diharapkan pihak pengabdi mampu memecahkan masalah melalui kegiatan pendampingan secara menyeluruh dan sustainable atau berkelanjutan.

Melalui kegiatan pengabdian yang dilakukan oleh Program Bisnis Universitas Nahdlatul Wathan Mataram, berbagai upaya dilakukan untuk mewujudkan Desa Pengadangan menjadi desa yang dikenal bersih dan mandiri.

Latar belakang yang menjadi alasan utama kegiatan pengabdian ini adalah masih belum terciptanya grand design yang mendukung kemandirian BMDes Bao Daya di Desa Pengadangan Kecamatan Pringgasela Lombok Timur, NTB. Oleh karena itu, pengabdian di Desa Pengadangan ini adalah pintu masuk untuk mengidentifikasi masalah yang ada di masyarakat Desa Pringgasela.

\section{METODE PELAKSANAAN}

Metode atau langkah pelaksanaan yang dilakukan yakni melakukan sosialisais bersama mitra dari kegiatan Pengabdian, yakni salah satu BUMN terbesar di Indonesia, yakni PT.Pegadaian (Persero)

Metode pelaksanaan kegiatan pengabdian ini melalui beberapa tahap sebagai berikut :
a. Tahap persiapan
b. Tahap survey lokasi atau observasi
c. Tahap pelaksanaan
d. Tahap penyusunan laporan

1. Tahap persiapan

Pada tahap ini dilakukan persiapan meliputi :

a. Penyiapan SDM, alat dan bahan, termasuk spanduk, dokumentasi dan alat yang lain, termasuk buku penunjang dalam pembuatan materi pengabdian masyarakat

b. Penentuan waktu pelaksanaan, serta lokasi kegiatan

c. Rapat pengabdian bersama anggota dan mahasiswa, yang terdiri dari beberapa dosen, serta didukung oleh unsur penujang, yakni mahasiswa, yang diisi 
dengan diskusi materi dan

teknis

pelaksanaan

pengabdian.

\section{Tahap Observasi}

a. Perwakilan Tim pengabdian berkonsultasi dengan mitra pengabdian, yakni BUMDes Bao Daya Desa Pengadangan Kecamatan Pringgasela, Lombok Timur, berkaitan dengan waktu yang tepat dan jumlah peserta pengabdian untuk pelaksanaan kegiatan.

b. Dalam melakukan kegiatan pengabdian, tim dari Fakultas Ilmu Administrasi dan fakultas Peternakan mengamati, mempelajari situasi dan kondisi objek sasaran pengabdian serta beberapa faktor yang mendukung sehingga dapat ditetapkan kegiatan altematif yang terbaik dari kegiatan tersebut.

\section{Tahap Pelaksanaan}

Dalam pelaksanaan kegiatan pengabdian, kelompok pengabdian dari Universitas Nahdlatul Wathan Mataram melaksanakan program kegiatan sesuai dengan peta atau arah pengabdian yang telah disusun sebelumnya dalam tahapan koordinasi atau rapat internal tim pengabdi. Tiap anggota kelompok secara bergiliran menyampaikan materi pengabdian sesuai dengan tugas masing-masing.

\section{HASIL DAN PEMBAHASAN}

Desa Pengadangan merupakan desa yang terletak di Kecamatan Pringgasela, Kabupaten Lombok Timur. Kecamatan Pringgasela sendiri merupakan kecamatan yang tergolong relatif masih muda karena baru terbentuk dan disahkan melalui Undangundang pada tahun 2000. Desa Pengadangan merupakan desa terluas di Kecamatan Pringgasela yaitu dengan luas sekitar $96,73 \mathrm{Km}^{2}$ atau $71,05 \%$ dari seluruh luas Kecamatan Pringgasela.

Desa Pengadangan Terletak di sebelah utara kota Selong, dengan jarak sekitar 11 kilometer, desa ini berbatasan dengan beberapa wilayah. Di sebelah utara, desa ini berbatasan dengan Taman Nasional Gunung Rinjani, sebelah selatan berbatasan dengan desa 
Pringgasela, sebelah timur berbatasan dengan desa Lenek Daya di Kecamatan Aikmel, dan sebelah barat berbatasan dengan Desa Jurit.

Dari sisi mata pencaharian mayoritas masyarakat berprofesi sebagai petani dengan komoditas utama padi, sayur mayur (seperti cabe rawit, tomat, dll), palawija, dengan jenis tanaman palawija di dominasi oleh tanaman jagung, kacang tanah, kedelai, dan cabai, serta tembakau Virginia. Dalam sistem pertanian, warga mengandalkan lahan kering untuk berkebun sedangkan lahan sawah hanya digunakan ketika musim hujan dengan sistem sawah tadah hujan.

Mata pencaharian lain yang dimiliki masyarakat adalah beternak. Untuk peternakan, di daerah ini masyarakat banyak yang memiliki sapi, bahkan sudah ada beberapa yang menerapkan teknologi biogas dengan memanfaatkan kotoran ternak. Selain pertanian dan peternakan, sektor industri juga menjadi salah satu lading pemasukan masyarakat. Jenis industri yang terdapat di desa ini antar lain industri batu / bata / genteng, perbengkelan, dan meubel.

Berikut adalah dokumentasi kegiatan diskusi, pendampingan dan penyuluhan pengabdian masyarakat di Desa Pengadangan Kecamatan Pringgasela Lombok Timur, NTB :

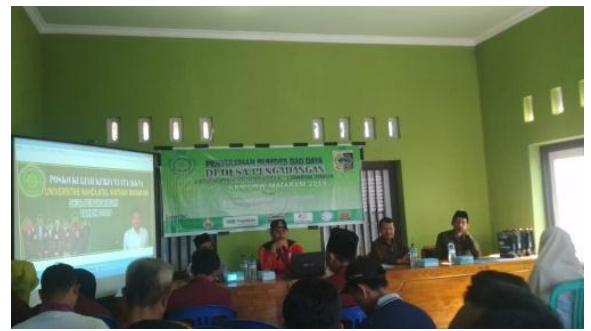

Gambar 1

Saat diskusi bersama BUMDes dan Mitra BUMDes, PT. Pegadaian Persero

Hasil dari diskusi pada gambar 1 adalah Pihak UNW (dalam hal ini diwakili dari akademisi Administrasi Bisnis), Pihak Desa, (khususnya pengelola BUMDes), dan pihak Mitra (PT. Pegadaian (Persero) sepakat untuk menjalin kerjasama berkelanjutan untuk memetakan dan menyusun bersama grand design atau design utama seperti apa yang butuhkan dalam rangka menguatkan posisi BUMDes sebagai salah satu wadah untuk menopang aktivitas masyarakat Desa Pengadangan agar menghasilkan tata social masyarakat yang baik dan utuh serta komprehensif.

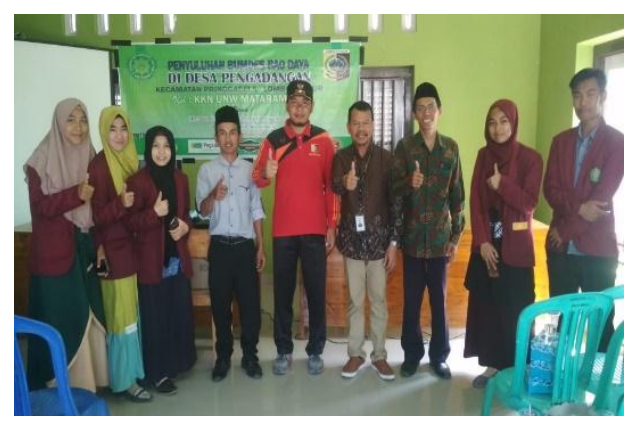


Gambar 2

Saat foto bersama pengelola Bumdes, Mitra dari BUMN, Pengabdi dan Mahasiswa kelompok pengabdian

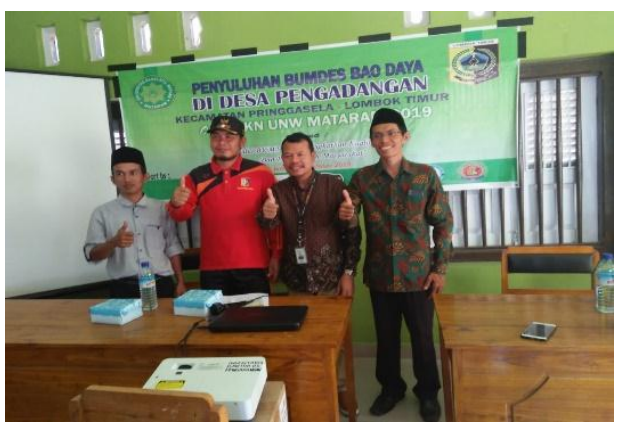

\section{Gambar 3. Pemateri/Pengabdi/Mitra}

Dalam sesi akhir kegiatan pengabdian, Penyamaan persepsi atau kesepakatan antara pemateri, pengabdi, dan pihak pengelola BUMDes Bao Daya Desa Pengadangan untuk mengadakan pertemuan lanjutan untuk kegiatan penguatan dan pengembangan serta pelebaran jaringan BUMDes Bao Daya

\section{UCAPAN TERIMA KASIH}

Ucapan terima kasih kami ucapakn kepada semua pihak atas terlaksananya Pengabdian kepada Masyarakat ini tidak lepas dari bantuan berbagai pihak, oleh karena itu pada kesempatan yang berbahagia ini penulis menyampaikan ucapan terima kasih serta penghargaan yang tak terhingga kepada :

1. Universitas Nahdlatul Wathan Mataram atas kesempatan yang diberikan kepada penulis untuk mengembangkan Tri Dharma

Perguruan Tinggi.

2. Desa Pengadangan Kecamatan Pringgasela Lombok Timur yang telah memberikan dukungan penyelenggaraan pengabdian kepada masyarakat.

\section{SIMPULAN}

Pelatihan dan pendampingan ini dapat meningkatkan pengetahuan dan ketrampilan BUMD dalam meningkatkan pengetahuan dasar dalam mengeloa BUMDes. Dalam rangkaian kegiatan tersebut, antusiasme masyarakat sangat tinggi dan program itu dapat diterima oleh masyarakat dengan baik.

Namun demikian, kegiatan pendampingan terhadap BUMDes Bao Daya harus terus dipantau secara langsung, karena membutuhkan waktu untuk observasi hasil diskusi yang lebih panjang.

\section{DAFTAR RUJUKAN}

Balaraja, Flyover, and Serang Banten.

Cianjur, Kabupaten. 2018. "Rancang Bangun Alat Pemisah Pasir Besi." 2(1): 16-18.

Kewirausahaan, Pengembangan et al. $2019 . \quad$ "Pengembangan Kewirausahaan Di Sma Negeri 1 Sunggal Kabupaten Deli Serdang Melalui Kegiatan Pelatihan 
Akuntansi.” 2(2): 110-19.

Lansia, Usia, D I Sleman, Rochana Rullyandari, and Ratu Matahari. 2017. "PELATIHAN PENINGKATAN KUALITAS HIDUP LANJUT.” 1(2): 295-300.

Pengabdian, Jurnal, and Kepada Masyarakat. 2018. "No Title." 2(1): 47-50.

Program, Dissemination. "Implementasi Mesin Pencampur Ragi Sistem."

Widiastuti, C Tri, and Rahmatya Widyaswati. 2018. "Peningkatan Kesejahteraan Keluarga Melalui Pelatihan Wirausaha Produk Camilan Sehat Stik Sea Food Bagi Ibu Rumah Tangga Di Kelurahan Mlatibaru Semarang." 2(1): 17-26. 